\title{
Processing of $\mathrm{LaCrO}_{3}$ for Solid Oxide Fuel Cell Applications
}

Topical Report

April 1994 - April 1995

July 1995

Work Performed Under Contract No.: DE-FG21-93MC29224

For

U.S. Department of Energy

Office of Fossil Energy

Morgantown Energy Technology Center

Morgantown, West Virginia

\section{By}

University of Missouri-Rolla

Rolla, Missouri 


\section{DISCLAIMER}

This report was prepared as an account of work sponsored by an agency of the United States Government. Neither the United States Government nor any agency thereof, nor any of their employees, makes any warranty, express or implied, or assumes any legal liability or responsibility for the accuracy, completeness, or usefulness of any information, apparatus, product, or process disclosed, or represents that its use would not infringe privately owned rights. Reference herein to any specific commercial product, process, or service by trade name, trademark, manufacturer, or otherwise does not necessarily constitute or imply its endorsement, recommendation, or favoring by the United States Government or any agency thereof. The views and opinions of authors expressed herein do not necessarily state or reflect those of the United States Government or any agency thereof.

This report has been reproduced directly from the best available copy.

Available to DOE and DOE contractors from the Office of Scientific and Technical Information, 175 Oak Ridge Turnpike, Oak Ridge, TN 37831; prices available at (615) 576-8401.

Available to the public from the National Technical Information Service, U.S. Department of Commerce, 5285 Port Royal Road, Springfield, VA 22161; phone orders accepted at (703) 487-4650. 


\title{
Processing of $\mathrm{LaCrO}_{3}$ for Solid Oxide Fuel Cell Applications
}

\author{
Topical Report \\ April 1994 - April 1995
}

Work Performed Under Contract No.: DE-FG21-93MC29224

\author{
For \\ U.S. Department of Energy \\ Office of Fossil Energy \\ Morgantown Energy Technology Center \\ P.O. Box 880 \\ Morgantown, West Virginia 26507-0880
}

\author{
By \\ University of Missouri-Rolla \\ B-47 McNutt Hall, UMR \\ Rolla, Missouri 65401
}

July 1995 


\section{Processing of $\mathrm{LaCrO}_{3}$ for \\ Solid Oxide Fuel Cell Applications}

CONTRACT INFORMATION

Contract Number

Contractor

Contractor Project Manager

Principal Investigators

METC Project Manager

Period of Performance

Schedule and Milestones
DE-FG21-93MC29224

University of Missouri - Rolla

Ceramic Engineering Department

222 McNutt Hall

Rolla, MO 65401

(314) $341-6129$

Wayne Huebner

Wayne Huebner

Harlan U. Anderson

Bruce Harrington

April 16, 1995 to April 15, 1996

FY95 Program Schedule

Influence of B-site Dopants on the Densification Behavior

Influence of B-site Dopants on the Conductivity and TEC

Effect of Stoichiometry of the Sintering Behavior of $\mathrm{LaCrO}_{3}$

Processing of Planar SOFC's with Varying Cathode \& Anode Microstructures

Processing of Planar SOFC's with Interfacial Modifications

$\begin{array}{lllllllllllll}\text { A } & \text { M } & \text { J } & \text { J } & \text { A } & \text { S } & \text { O } & \text { N } & \text { D } & \text { J } & \text { F } & \text { M }\end{array}$

$\leftarrow$
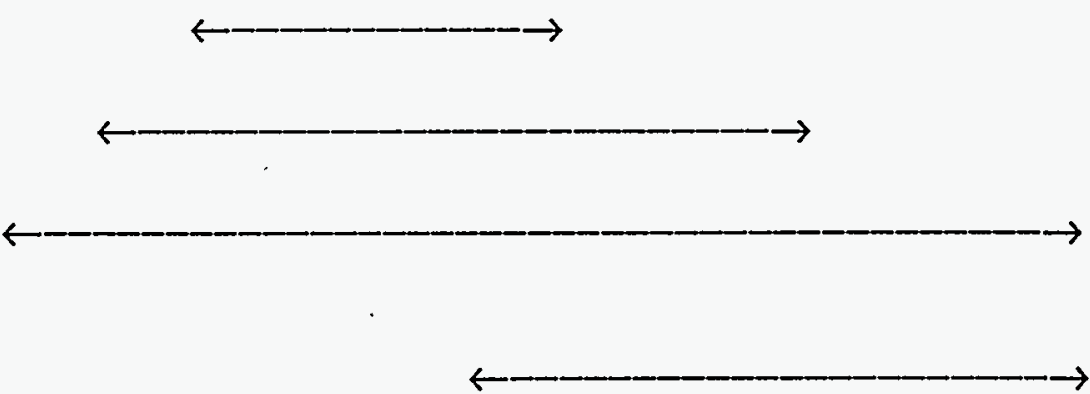


\section{OBJECTIVES}

The University of Missouri-Rolla is performing a 5 year research program with two primary objectives: 1) developing $\mathrm{LaCrO}_{3}$-based interconnect powders which densify when in contact with anode and cathode materials for solid oxide fuel cells (SOFC), and 2) developing high performance cathodes, anodes and interfaces for use in planar SOFC's.

With regard to the processing and sintering of $\mathrm{LaCrO}_{3}$, the specific objectives of this research program are to:

- Develop a non-liquid phase sintered $\mathrm{LaCrO}_{3}$-based materiạl sinterable in air.

- Improve and control the properties requisite of $\mathrm{LaCrO}_{3}$ utilizing a $\mathrm{B}$-site acceptor dopant

- Optimize and control the processing conditions associated with $\mathrm{LaCrO}_{3}$.

- Incorporate materials developed in this program into planar cells and measure their performance.

With regard to developing high performance materials for use in planar SOFC's, the specific objectives of this research program over the last year have been to:

- Fabricate single cells with controlled microstructures (i.e. grain size and porosity of electrodes) for operation at $1000^{\circ} \mathrm{C}$.

- Gain a better understanding of the mechanisms involved in improving cell performance via electrochemical and impedance techniques.

- Develop processing $\leftrightarrow$ microstructure $\leftrightarrow$ property relations of electrodes and their corresponding interfacial reactions.

\section{BACKGROUND INFORMATION}

One of the primary factors limiting the commercialization of SOFC's is the inability to fabricate $\mathrm{LaCrO}_{3}$-based interconnects cheaply, and in contact with other SOFC components. The very properties which make $\mathrm{LaCrO}_{3}$ a good interconnect material, also make it very difficult to sinter. Microstructural evolution $\leftrightarrow$ property relationships of the $\mathrm{LaCrO}_{3}$-based interconnect need to be understood. This was recently confirmed again at the SOFC IV conference held in Yokohama, Japan. At this meeting numerous research groups identified the cost of processing $\mathrm{LaCrO}_{3}$ was prohibitive, as well as its tendency to change dimensions upon reduction. Indeed, the inability to co-sinter $\mathrm{LaCrO}_{3}$-based compounds in air at $\mathrm{T}<1550^{\circ} \mathrm{C}$ with other SOFC components leads to unacceptable interfacial reactions, and resultant losses in efficiency. Many researchers have addressed this problem, yet progress has been hindered due to recognized difficulties in repeatable processing. Phase development, stoichiometry, particle size/distribution, agglomerate/ aggregate formation, volatility of components, and their dependence on dopant levels and sintering temperature, time and atmosphere are very difficult to systematically take into account.

The results of our work and other investigators ${ }^{2-}$ 10 have lead us to the conclusion that the densification of $\mathrm{LaCrO}_{3}$-based oxides is controlled by the ability for mass transport (sintering) to occur under conditions which minimize $\mathrm{Cr}$ oxide volatilization ( $\mathrm{Cr}$ activity, $\mathrm{a}_{\mathrm{Cr}}$ ). We demonstrated that this could be accomplished by sintering at temperatures $>1750^{\circ} \mathrm{C}$ and oxygen activities of about $10^{-10} \mathrm{~atm}^{2}$ but clearly these sintering conditions are not compatible with the stability of other SOFC components. Another approach to reduce $\mathrm{a}_{\mathrm{Cr}}$ is to lower the sintering temperature with liquid fluxes, which was initially pursued by Argonne National Labs ${ }^{8}$. However, the high mobility of the fluoride fluxes detrimentally affected the other cell components. More recent studies including our own have also shown that while transient liquid phase sintering may allow for lower temperature densification of the interconnect alone, the use of large amounts of A-site dopants (i.e. $\mathrm{Ca}, \mathrm{Sr}$ ) in amounts excess of stoichiometry create problems with second phase formation and limited mechanical stability in reducing atmospheres. Hence in some ways we are back to square one, and in this program we have refocused our attention on densifying acceptor-doped $\mathrm{LaCrO}_{3}$ without the addition of a liquid phase. 
Materials research in the area of SOFC's is also driven by the recognition that processing and operating at lower temperatures would circumvent most of the reliability problems which are currently preventing these devices from achieving wide-scale commercialization. These considerations have directed interdisciplinary research thrusts in this field, namely:

\section{- Alternate Materials}

$\rightarrow$ higher conductivities at lower temperatures for all four SOFC components

$\rightarrow$ mixed-conducting cathodes

$\rightarrow$ greater phase stability at low $\mathrm{pO}_{2}$ 's

\section{- Processing}

$\rightarrow$ novel synthesis techniques (for powders and thin films)

$\rightarrow$ controlled microstructure with desired properties

- Reliability Issues

$\rightarrow$ chemical, mechanical, and electrical stability under the temperature/time/atmosphere conditions of cofiring and operation

Hence studies on the optimization of components use of mixed conductors and thin film processing techniques ${ }^{11-16}$, as well as studies on structure $\leftrightarrow$ property relationships represent an enabling technology; what remains is to utilize this technology for the fabrication of planar SOFC's. Key to this next stage is the development of a porous anode substrate with the requisite microstructural, electrical and mechanical properties. While many researchers have investigated $\mathrm{Ni}: \mathrm{ZrO}_{2}$ cermet anodes ${ }^{7}$, many issues related to microstructural evolution and stability, as well as the impact of $\mathrm{Ni}$ scale and connectivity on the electrical properties remain unresolved.

\section{PROJECT DESCRIPTION}

This report is divided into two primary sections:

\section{\#1 $\mathrm{LaCrO}_{3}$ Sintering Studies}

\#2
Results from these studies are presented in the following sections.

\section{$\mathrm{LACrO}_{3}$ SINTERING STUDIES}

\section{Experimental Approach:}

Powders of the composition $\mathrm{LaCr}_{1-\mathrm{x}} \mathrm{M}_{\mathrm{x}} \mathrm{O}_{3}$ were prepared by a modified liquid mix process, in which ethylene glycol and citric acid are added to a stoichiometric mixture of carbonates and nitrates of the constituent ions in a 1:1:1 ratio. Starting . materials were thermogravimetrically standardized to $\pm 0.1 \mathrm{mg}$ and $x$-rayed to ensure correct oxide composition. BET measurements indicate resulting powders have a specific surface area of $\sim 5.0 \mathrm{~m}^{2} / \mathrm{g}$. Sintering studies were conducted with $1 / 2$ " pellets uniaxially pressed to $3 \mathrm{ksi}$ and isostatically pressed to 40ksi. Green densities were taken geometrically, while final densities were measured by the Archimedes technique with kerosene as the medium. Sintering studies were performed on an Orton $1600 \mathrm{D}$ dilatometer with $1 / 4$ " pellets uniaxially pressed to $0.2 \mathrm{ksi}$ and isostatically pressed to $40 \mathrm{ksi}$. Crystallinity and phase purity were determined by x-ray on a Rigaku Miniflex system. Conductivity was determined with a 2point d.c. apparatus with platinum electrodes over the temperature range of $25-1300^{\circ} \mathrm{C}$.

\section{RESULTS}

\section{A) Sintering}

Recent studies in our laboratory have shown that compositions of $\mathrm{LaCr}_{1-\mathrm{x}} \mathrm{M}_{\mathrm{x}} \mathrm{O}_{3}$ with $\mathrm{x}<0.10$ exhibit enhanced sintering in air at temperature up to $1600^{\circ} \mathrm{C}$. X-ray and TGA results (Figures 1 and 2) show that the material remains phase pure perovskite throughout the temperature range and that no apparent liquid is formed in the material. Figure 3 shows densification studies performed at $1600^{\circ} \mathrm{C} / 6 \mathrm{hrs}$ as a function of dopant concentration. Despite problems with the processing resulting in green densities of $48-51 \%$ theoretical density, samples were still found to sinter to $90 \%$ of theoretical density. The relative densities level off with about $7 \%$ dopant additions. Figure 4 shows a polished and thermally etched 


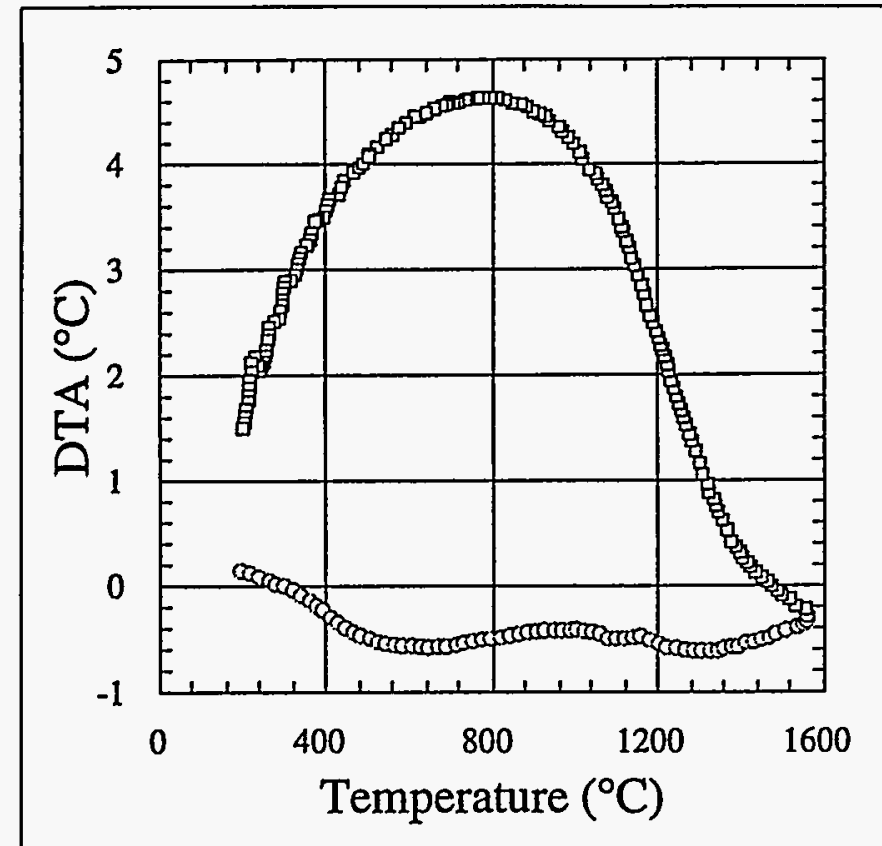

Figure 1: DTA Results on LaCro.9 $\mathrm{M}_{0.1} \mathrm{O}_{3}$

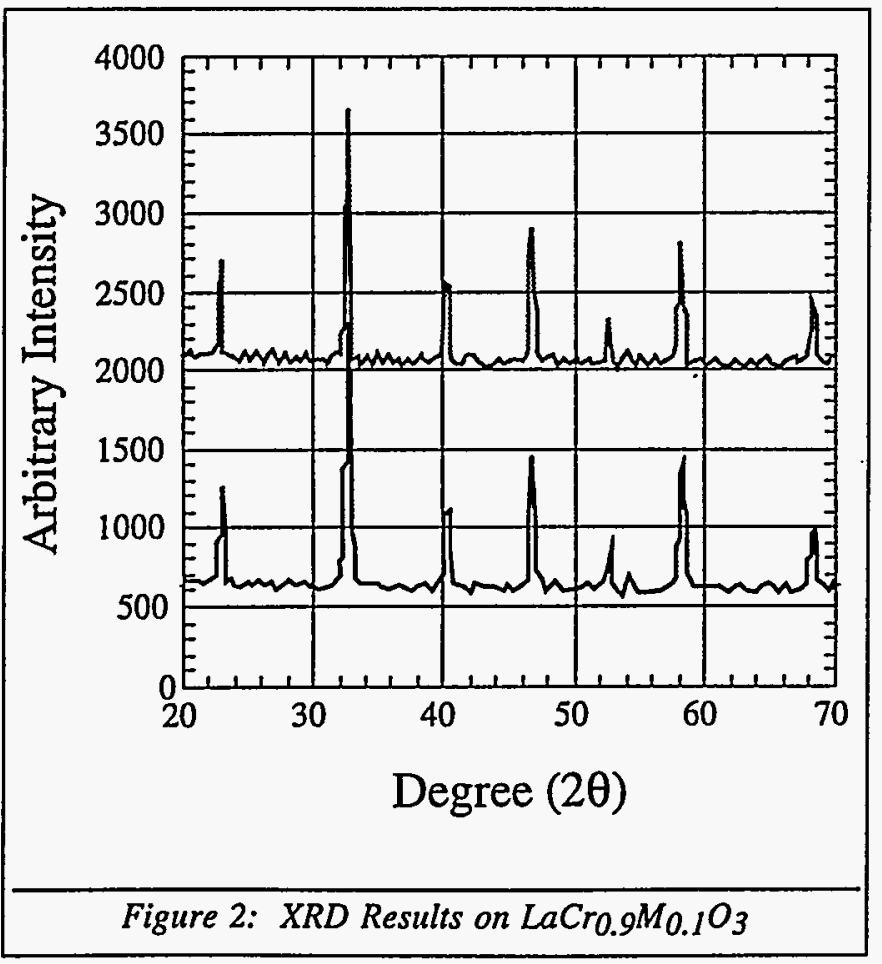

specimen of $\mathrm{LaCr} .90 \mathrm{M} .10 \mathrm{O}_{3}$ corresponding to a relative density of $\sim 90 \%$. Tests on the effects of stoichiometry were performed for lanthanum contents of $0.98,0.99$, and 1.00 . Figure 5 shows
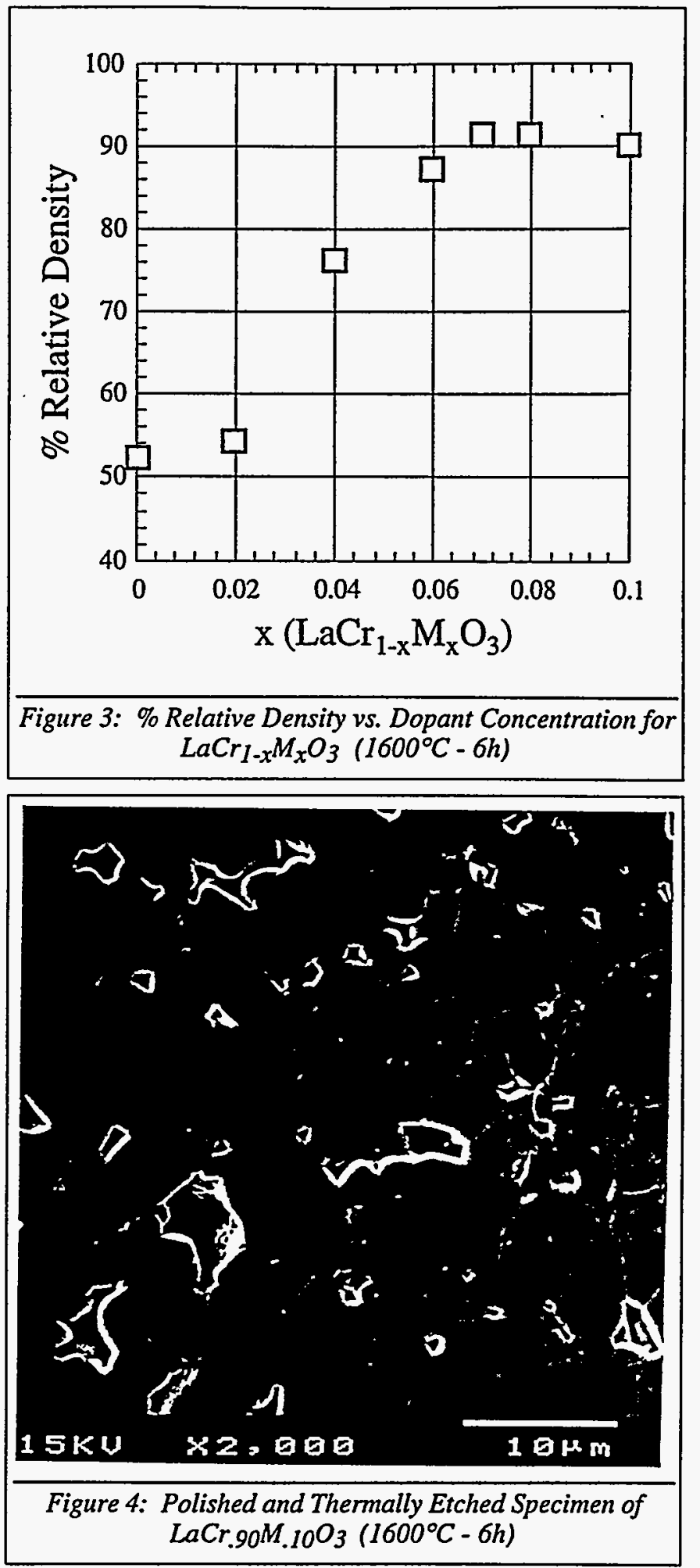

that when the lanthanum content is reduced $1 \%$ to a nominal composition of $\mathrm{La} .99 \mathrm{Cr} .90 \mathrm{M}_{10} \mathrm{O}_{3}$ the 


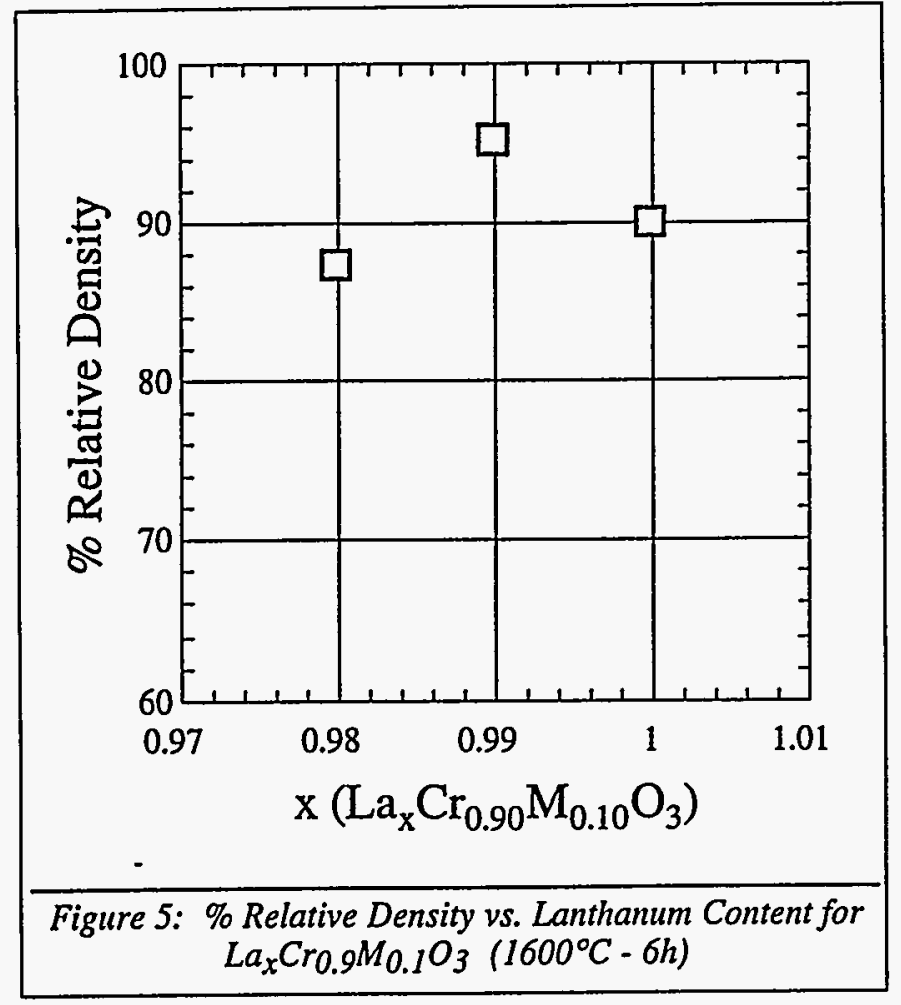

relative density is increased to $95 \%$. Figures 6 and 7 show a polished and thermally etched La. ${ }_{99} \mathrm{Cr} .90 \mathrm{M} .10 \mathrm{O}_{3}$ specimen . The percent linear shrinkage of $\mathrm{La} .99 \mathrm{Cr} .90 \mathrm{M} .10 \mathrm{O}_{3}$ is shown is figure 8 , with the sample exhibiting $\sim 28 \%$ shrinkage to a final relative density of $\sim 90 \%$ after 6 hours at $1600^{\circ} \mathrm{C}$. Sintering starts at $-1100^{\circ} \mathrm{C}$ reaching a shrinkage of $17 \%$ before the hold at $1600^{\circ} \mathrm{C}$. Further results have shown that 4 hrs is sufficient to reach the maximum shrinkage. Improvements in processing related issues should allow for even higher sintered densities to be achieved, possibly allowing the lowering of the sintering temperature. Current work is focusing on theses issues.

\section{B) Property Control}

Preliminary studies have shown that $\mathrm{La} .99 \mathrm{Cr} .90 \mathrm{M} .10 \mathrm{O}_{3}$ has a conductivity of $\sim 8 \mathrm{~S} / \mathrm{cm}$ at $1000^{\circ} \mathrm{C}$, sufficient for fuel cell applications (Figure 9). As seen in figure 10 the plot of $\log \left(\sigma^{*} \mathrm{~T}\right)$ vs. $1000 / \mathrm{T}$ is linear, as is expected under a smallpolaron model. Current work is progressing on the evaluation of other properties such as:

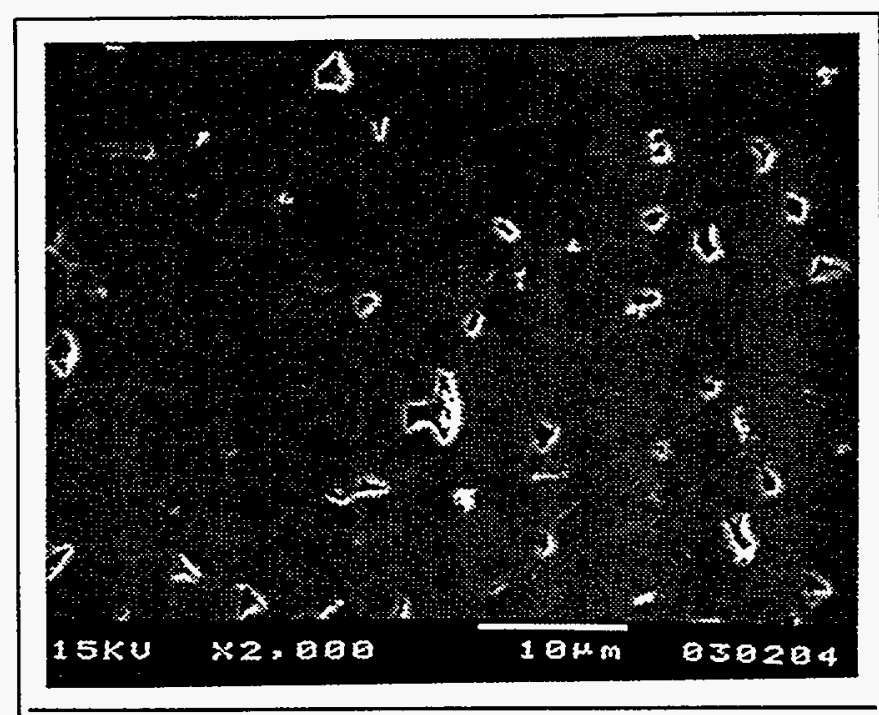

Figure 6: Polished and Thermally Etched Specimen of $\mathrm{La} .99 \mathrm{Cr} .90 \mathrm{M} .10^{\circ} \mathrm{O}_{3}\left(1600^{\circ} \mathrm{C}-6 \mathrm{~h}\right)$

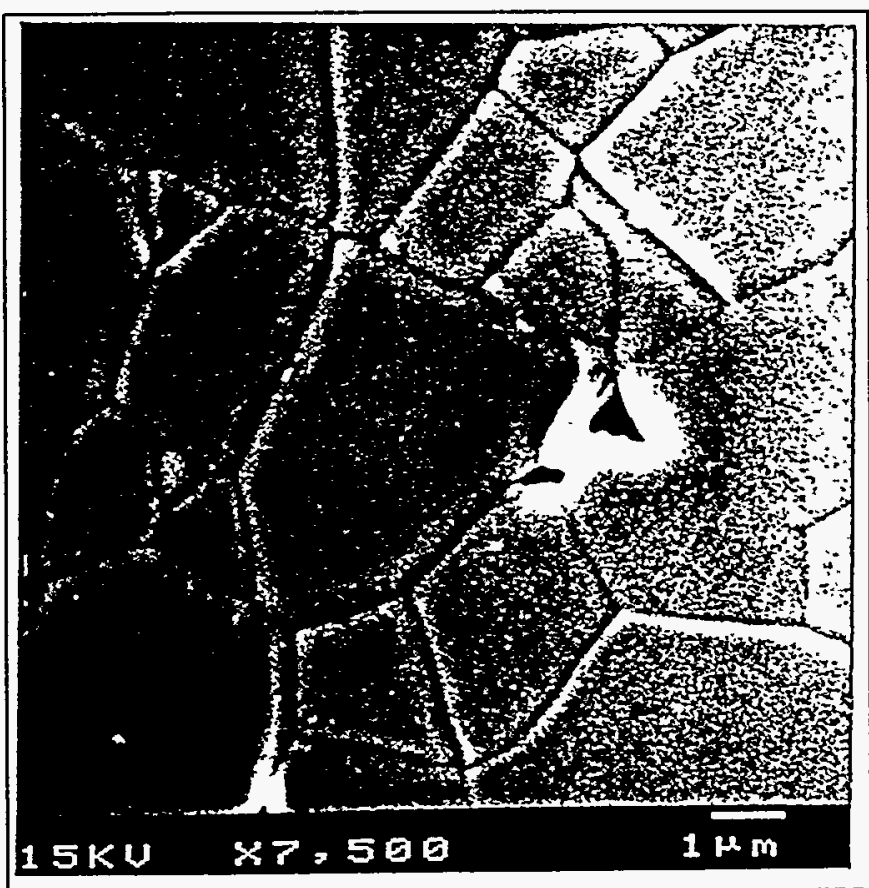

Figure 7: Polished and Thermally Etched Specimen of $\mathrm{La} .99 \mathrm{Cr} .90 \mathrm{M} .10 \mathrm{O}_{3}\left(1600^{\circ} \mathrm{C}-6 \mathrm{~h}\right)$

mechanical and electrical integrity under ambient and hydrated reducing conditions, match of thermal expansion with other cell components, and long term chemical stability with other materials in the fuel cell. 

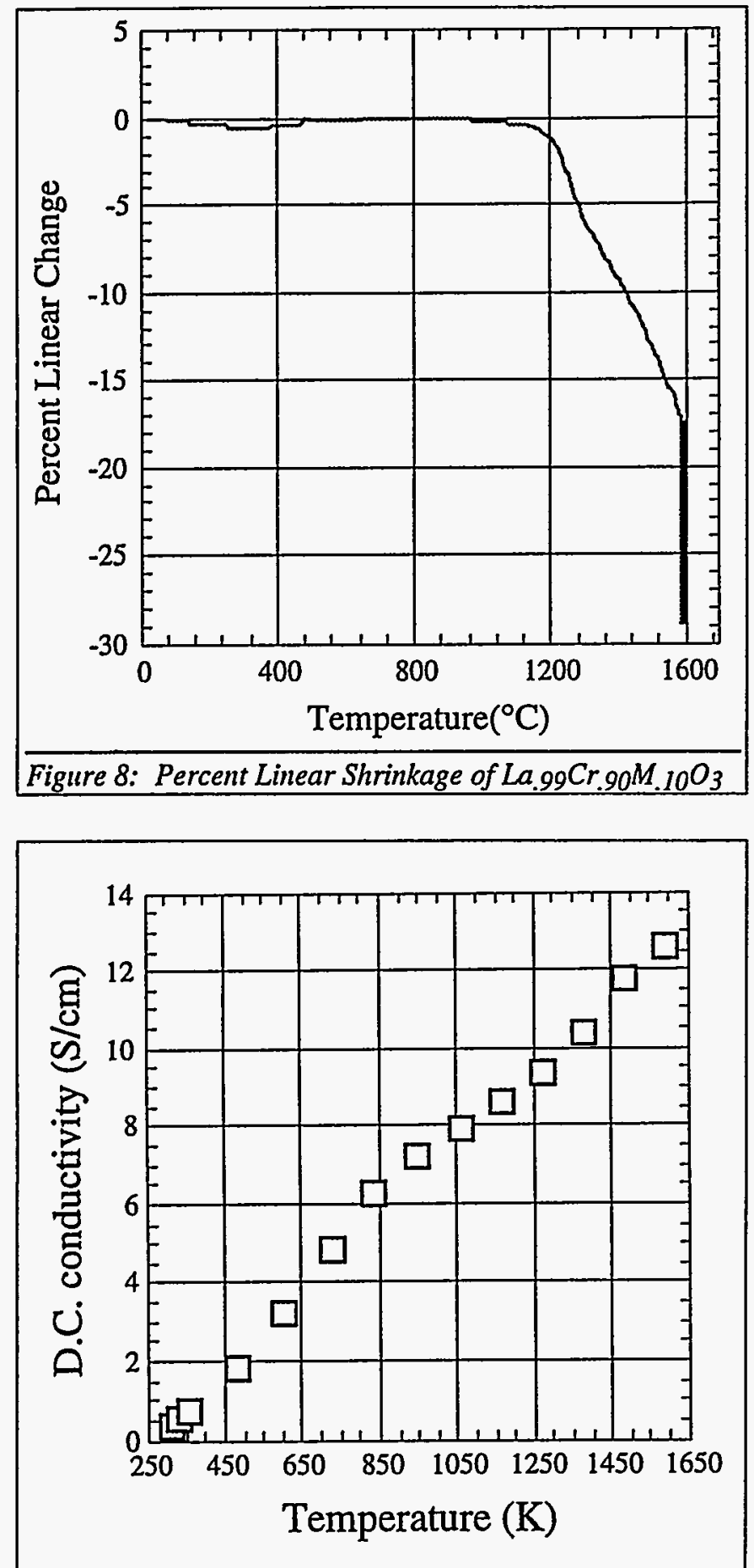

Figure 9: DC Conductivity of $\mathrm{La} .99 \mathrm{Cr} .90 \mathrm{M} .10 \mathrm{O}_{3}$ sintered at $1600^{\circ} \mathrm{C}-6 \mathrm{~h}$

Major Achievement: The development of a non-liquid phase sintered $\mathrm{LaCrO}_{3}$-based interconnect system that utilizes a B-site dopant.

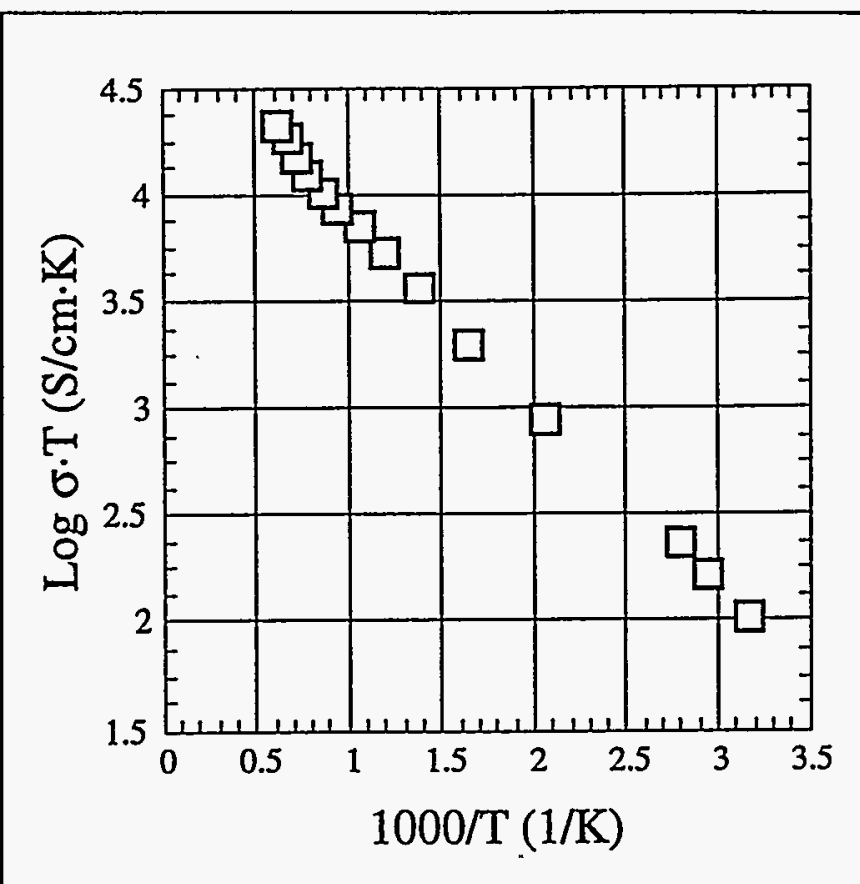

Figure 10: Arrhenius Plot of the DC Conductivity of La. ${ }_{99} \mathrm{Cr} .90 \mathrm{M}_{.10} \mathrm{O}_{3}$ sintered at $1600^{\circ} \mathrm{C}-6 \mathrm{~h}$

\section{SOFC PERFORMANCE STUDIES}

In this portion of the research we are focusing on the microstructure $\leftrightarrow$ property relations in solid oxide fuel cells (SOFC's) to better understand the mechanisms involved in cell performance. The aim is to fabricate SOFC's with controlled microstructures utilizing $\mathrm{La}_{1-\mathrm{x}} \mathrm{Sr}_{\mathrm{x}} \mathrm{MnO}_{3}$ (LSM), yttria stabilized zirconia (YSZ), and $\mathrm{Ni}$-YSZ composites as the cathode, electrolyte, and anode, respectively. The specific objectives of this research project are to:

$\rightarrow \quad$ Fabricate SOFC components with controlled microstructures (i.e. grain size and porosity of the cathode/anode).

$\rightarrow$ Gain a better understanding of the mechanisms involved in improving cell performance via electrochemical and impedance techniques, and correlate these results to the microstructure. phases:

This aspect of the project is divided into three 
I. Construct a system for measuring planar SOFC's

II. Processing and forming of trilayer structures of anode/electrolyte/cathode

III. Electrical characterization of single cells by electrochemical and impedance techniques.

Phase I was completed during Year 2, whereas Phases II and III are presently ongoing.

\section{Experimental Approach:}

\section{Sample Preparation}

Single cells were fabricated by conventional thick film processing techniques as described in Figure 11. Commercial YSZ powder (Zirconia Sales of America) was mixed with appropriate binders, solvents, plasticizers, and surfactants to prepare a castable slip. The slip was ball milled with $\mathrm{ZrO}_{2}$ media then cast at a thickness of 10 mils using the doctor blade technique. Circular samples were punched out of the tape and a thin Pt reference probe was screen printed onto the YSZ tape. The samples were laminated and fired flat at $1450^{\circ} \mathrm{C}$ for 2 hours. Fired thicknesses of the Pt reference electrode and the YSZ electrolyte are 5 and $200 \mu \mathrm{m}$, respectively (Figures 12 and 13).

Anode powders of $\mathrm{NiO}, \mathrm{Ni}_{1-\mathrm{x}} \mathrm{Mg}_{\mathrm{x}} \mathrm{O}$, YSZ (Zirconia Sales of America) and Sm doped $\mathrm{CeO}_{2}$ were used as starting materials. $\mathrm{NiO}, \mathrm{Ni} 1-\mathrm{x} \mathrm{Mg}_{\mathrm{x}} \mathrm{O}$, and $\mathrm{Sm}$ doped $\mathrm{CeO}_{2}$ were prepared by the Pechini liquid mix and glycine -nitrate methods to give powders of varying particle size and surface area. Powder crystallinity, phase and surface area were characterized by X-ray diffraction and BET techniques as a function of calcination temperature. Anode powders were mixed with appropriate binders, solvents, and surfactants and three roll milled to prepare high viscosity pastes with correct rheological behavior for screen printing. Anode pastes were screen printed onto dense YSZ electrolytes and fired at various temperatures (1200 $-1500^{\circ} \mathrm{C}$ ). A typical anode microstructure, $\mathrm{NiO}$ YSZ, fired in air is shown in Figure 14. The anode thickness can be varied depending on the mesh size, emulsion thickness, and wire diameter of the screen.
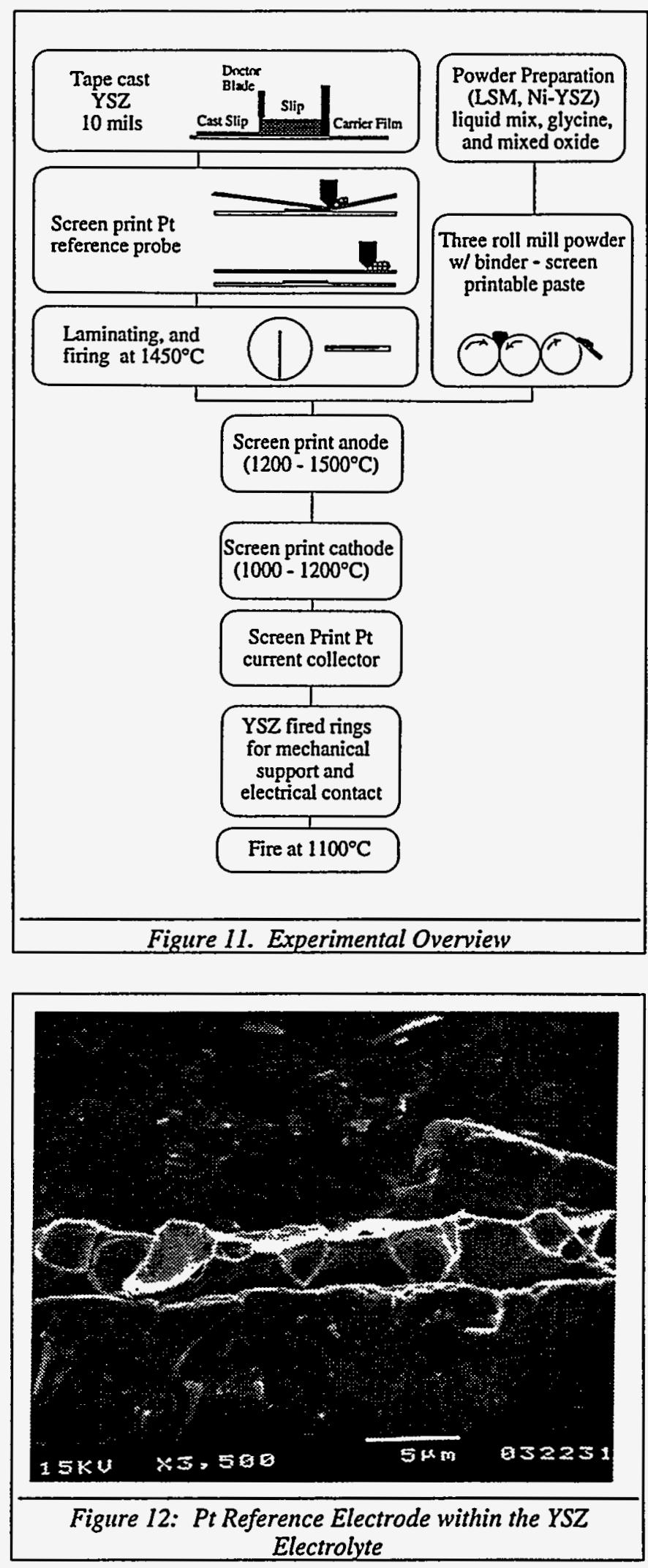


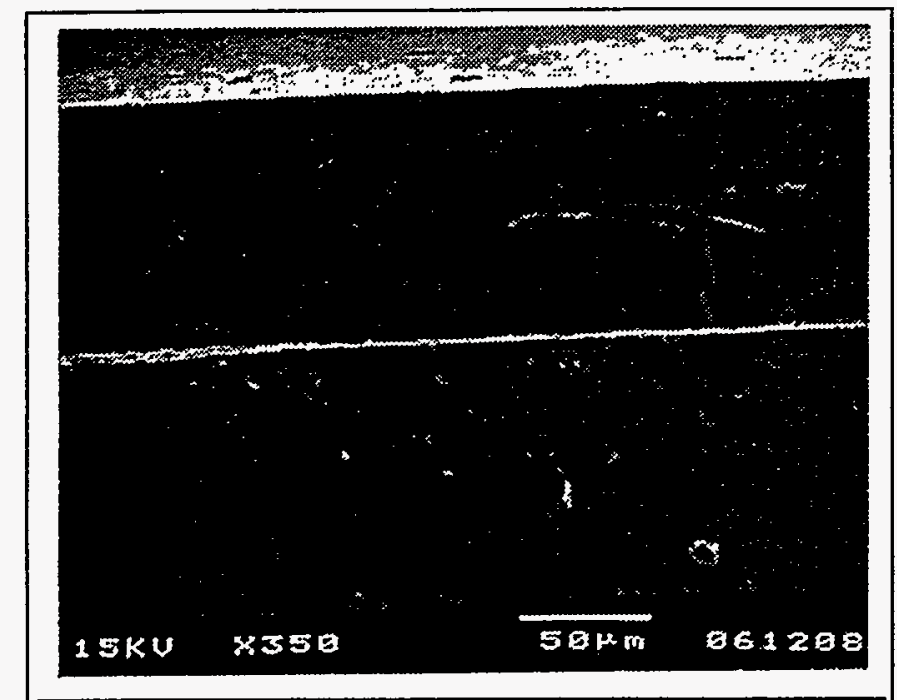

Figure 13: Pt Reference Electrode within the YSZ Electrolyte

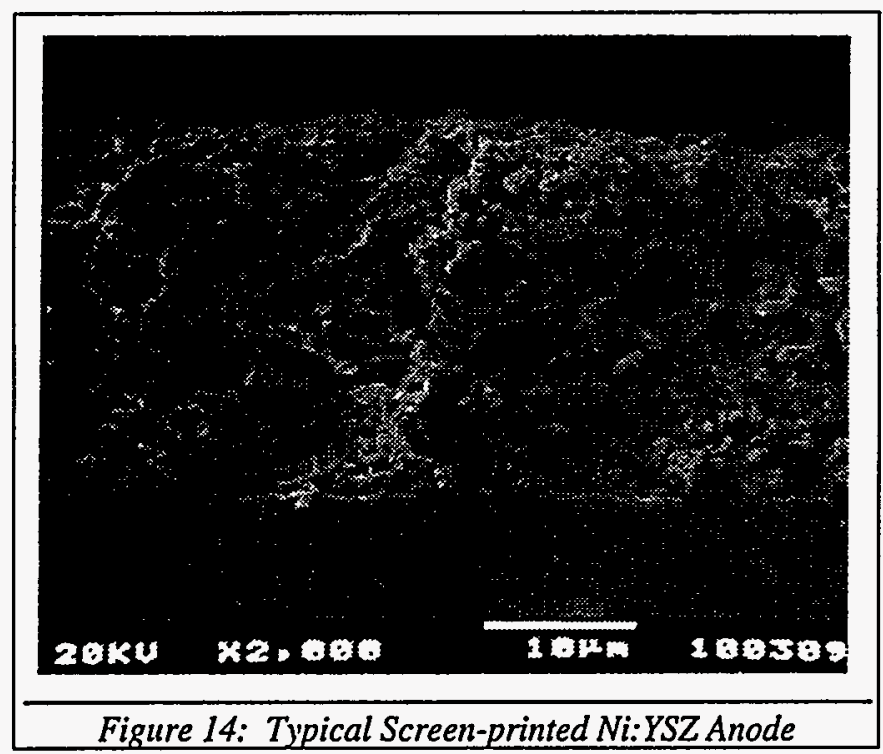

Different cathode powders of composition $\mathrm{La}_{0.79} \mathrm{Sr}_{0.2} \mathrm{MnO}_{3}$ (LSM-20) were made by various techniques (Pechini liquid mix, glycine - nitrate, and mixed oxide) to give powders of varying particle size and surface area. Powder crystallinity, phase and surface area were characterized by X-ray diffraction and BET techniques as a function of calcination temperature. Cathode powders were prepared into pastes by a similar method as described above, screen printed onto the YSZ electrolyte and fired at various temperatures (1000 $\left.1200^{\circ} \mathrm{C}\right)$. Various cathode microstructures have been developed for the same firing temperature $\left(1100^{\circ} \mathrm{C} / 1\right.$ hour) with different processing techniques (Figures $15-18$ ).

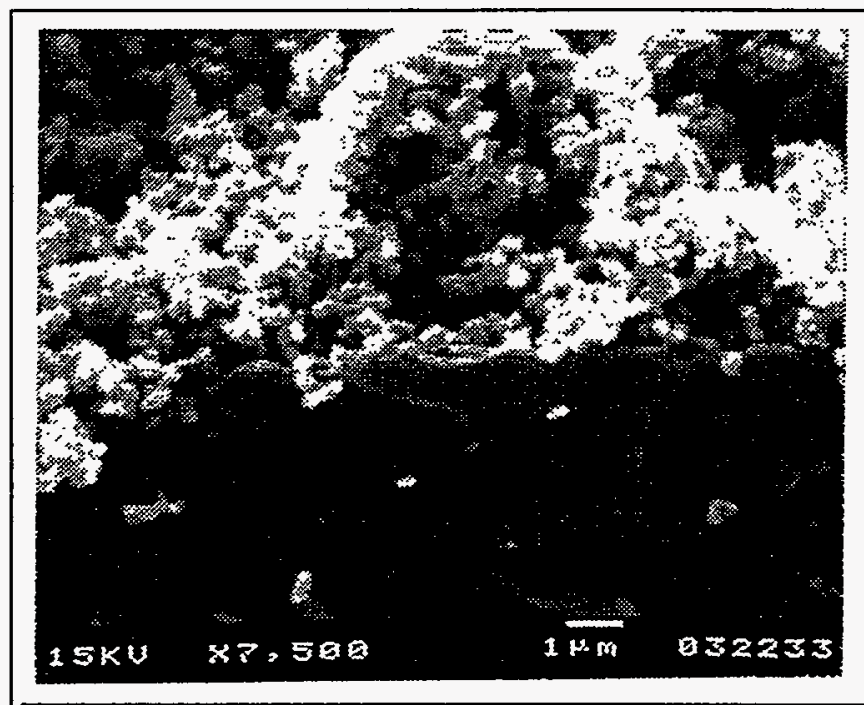

Figure 15: Screen Printed LSM Cathode $\rightarrow$ Glycine Nitrate Precursor Calcined at $800^{\circ} \mathrm{C}-1 \mathrm{~h}$; fired on at $1100^{\circ} \mathrm{C}-\mathrm{Ih}$.

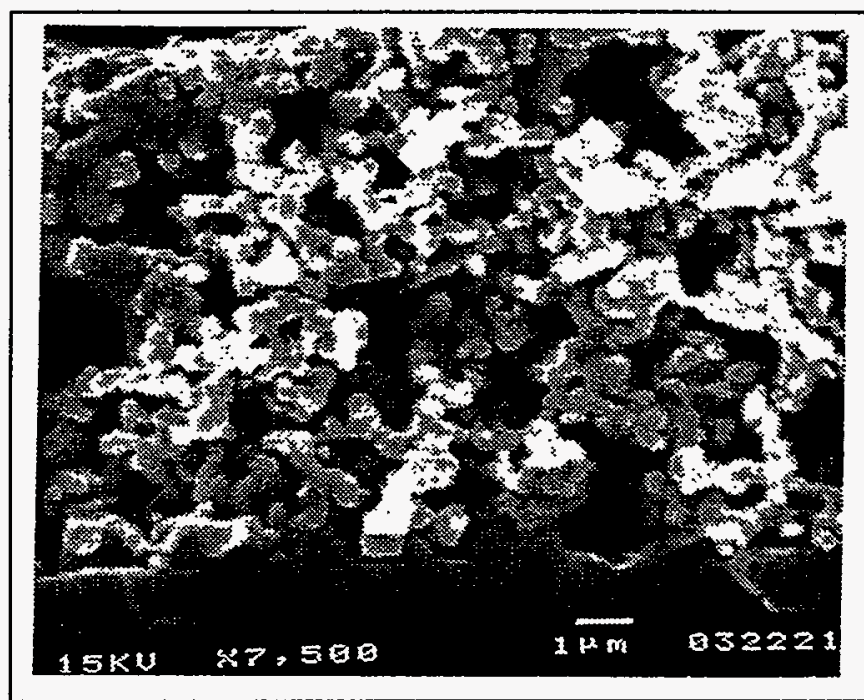

Figure 16: Screen Printed LSM Cathode $\rightarrow$ Pechini Precursor Calcined at $900^{\circ} \mathrm{C}-\mathrm{Ih}$; fired on at $1100^{\circ} \mathrm{C}-\mathrm{Ih}$.

A Pt current collector was printed onto the LSM20 to mimic a Pt mesh screen. A typical microstructure of the Pt current collector is given in Figure 19.

Dense YSZ rings with a thickness of $\sim 400 \mu \mathrm{m}$ were cemented on both sides of the electrolyte for mechanical support and electrical contact. 


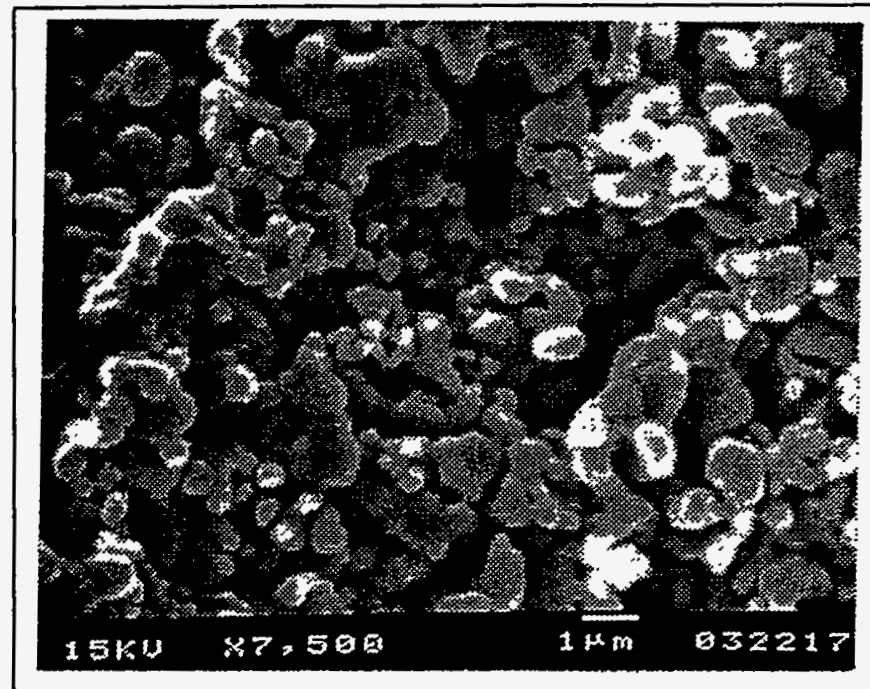

Figure 17: Screen Printed LSM Cathode $\rightarrow$ Pechini Precursor Calcined at $1100^{\circ} \mathrm{C}-1 \mathrm{~h}$; fired on at $1100^{\circ} \mathrm{C}-1 \mathrm{~h}$.

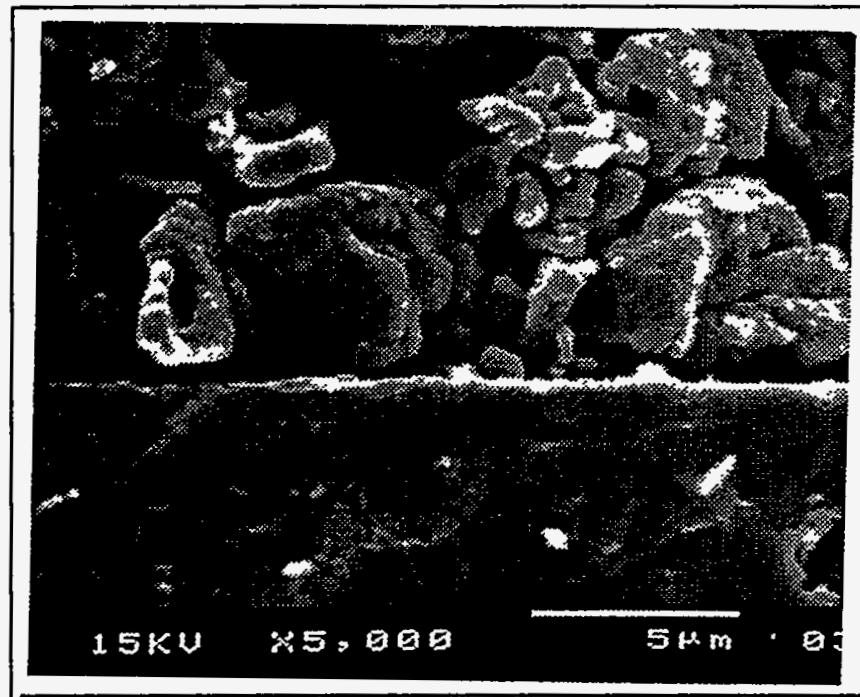

Figure 18: Screen Printed LSM Cathode $\rightarrow$ Mixed Oxides Calcined at $1100^{\circ} \mathrm{C}-1 \mathrm{~h}$; fired on at $1100^{\circ} \mathrm{C}-1 \mathrm{~h}$.

\section{Sample Characterization}

The system built for measuring cell performance is shown in Figure 20. The apparatus is a two tube design capable of operating at temperatures up to $1100^{\circ} \mathrm{C}$. The oxygen activity of the oxidant and fuel is controlled by mass flow controllers and the $\mathrm{pO}_{2}$ is monitored using a $\mathrm{ZrO}_{2}$ sensor. Partial pressures of $\mathrm{O}_{2}$ are controlled by $\mathrm{O}_{2}-\mathrm{N}_{2}$ mixtures or air on the cathode side and $\mathrm{H}_{2}-\mathrm{H}_{2} \mathrm{O}$, and $\mathrm{H}_{2}$ $\mathrm{N}_{2}-\mathrm{CO}_{2}$ mixtures on the anode side. Values obtained from the $\mathrm{ZrO}_{2}$ sensor are in good

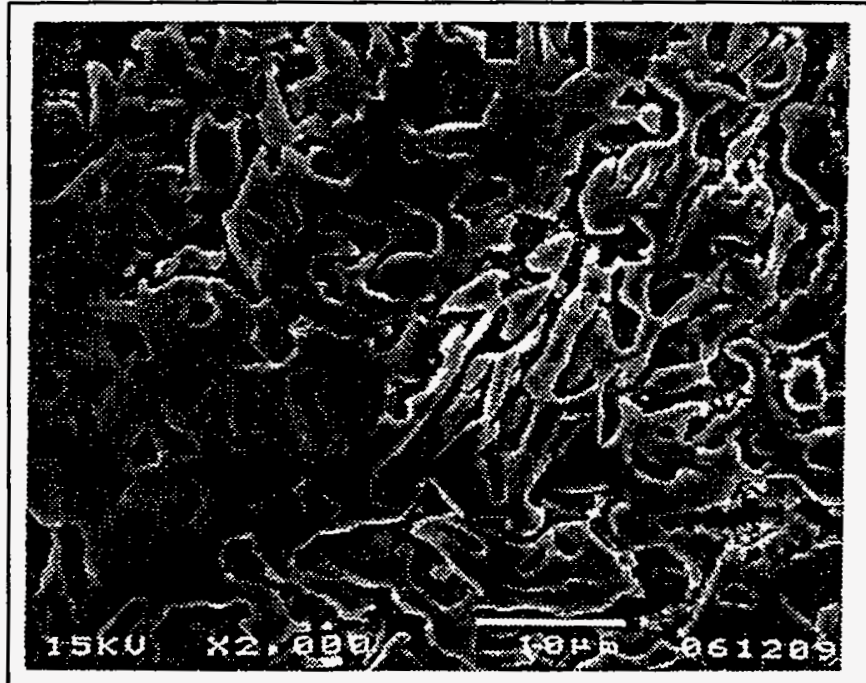

Figure 19: Screen Printed Pt Current Collector.

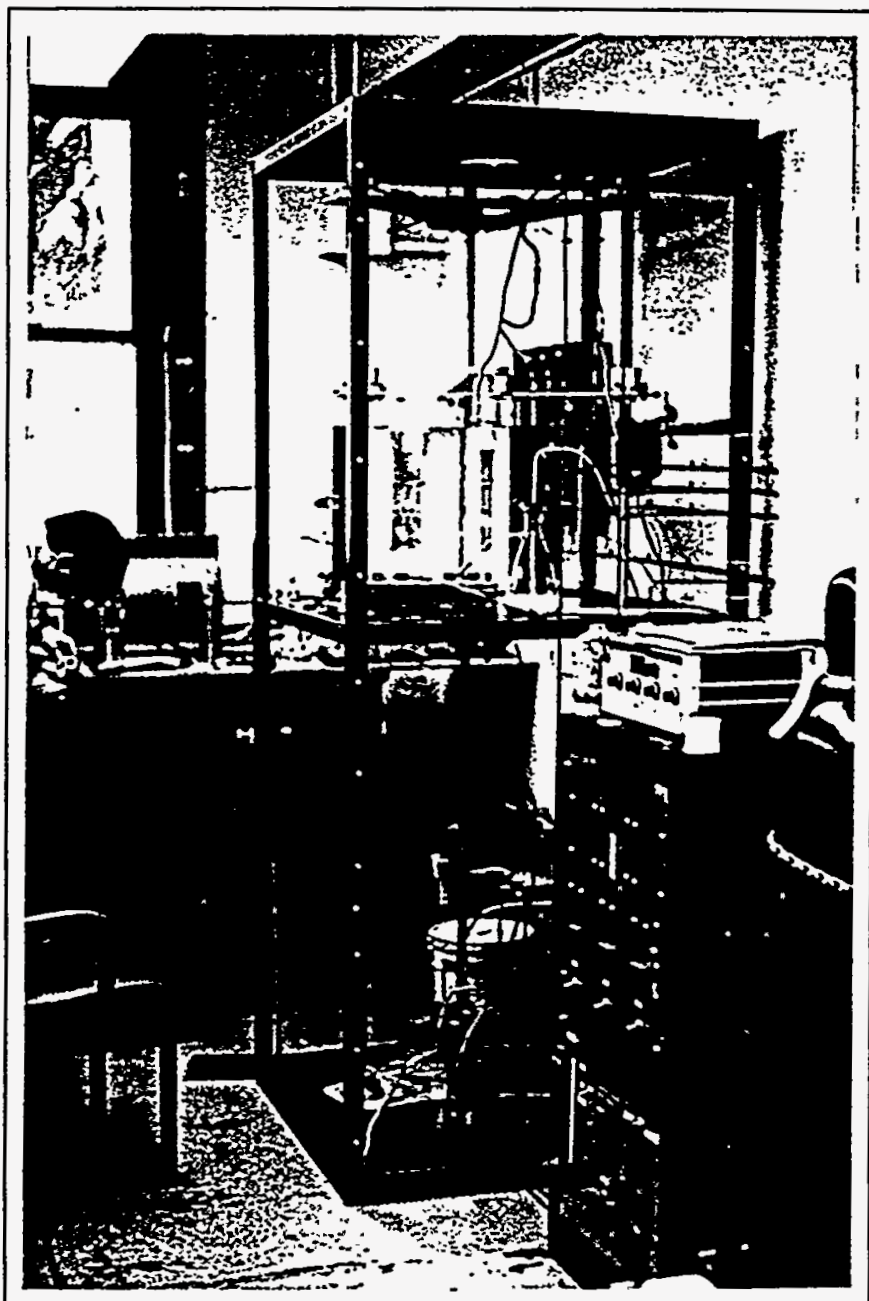

Figure 20: Cell Measurement System 
agreement with values derived from thermodynamic data.

Electrochemical measurements are carried out using a three electrode configuration which allows for separation of electrode effects during operation. Pt lead wires are used on the cathode side for electrical connection to both the cathode and reference electrodes while $\mathrm{Ni}$ wire is used on the anode side. Electrical characterization, I - V, current density, and interfacial characterization, is performed using a Keithley 197 Microvolt DMM, a Hewlett Packard 4192A Impedance Analyzer, and a computer controlled Solartron Electrochemical Interface (1286) and Impedance/Gain-Phase Analyzer (1260).

\section{RESUlTS AND DISCUSSION}

Electrochemical data obtained at present has been focused on the overpotential associated with the anode, namely, coarsening of the $\mathrm{Ni}$ particles. All cell have an effective electrolyte thickness of $200 \mu \mathrm{m}$ with a Pt reference electrode buried in the center of the electrolyte. The same cathode

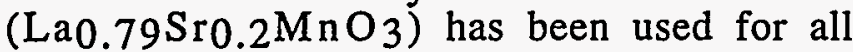
experiments and was fired on the electrolyte at $1100^{\circ} \mathrm{C}$ for 1 hour. The only variables to present are the anode composition, $\mathrm{Ni}$ content, firing temperature, and gas composition.

Experiments were initially performed on YSZ$\mathrm{NiO}$ anodes containing 43 volume \% $\mathrm{Ni}$ after reduction with various firing temperatures $(1250$, 1300,1400 , and $1500^{\circ} \mathrm{C}$ ). Cells were measured with air as the oxidant and a $\mathrm{H}_{2}-\mathrm{N}_{2}-\mathrm{CO}_{2}$ mixture as the fuel. The theoretical open circuit voltage is $1.00 \mathrm{~V}$. Plots of cell voltage, anode overpotential, and cathode overpotential versus current density measured under load are given in Figure 21. Anode and cathode overpotentials are the voltages measured from the electrodes (cathode or anode) to the Pt reference electrode and do not include any IR losses associated with the anode, cathode, and electrolyte. The IR drop across the electrolyte and anode at the given current density does not have any significant contribution to the total anode overpotential although the IR loss across the cathode may contribute to the total cathode

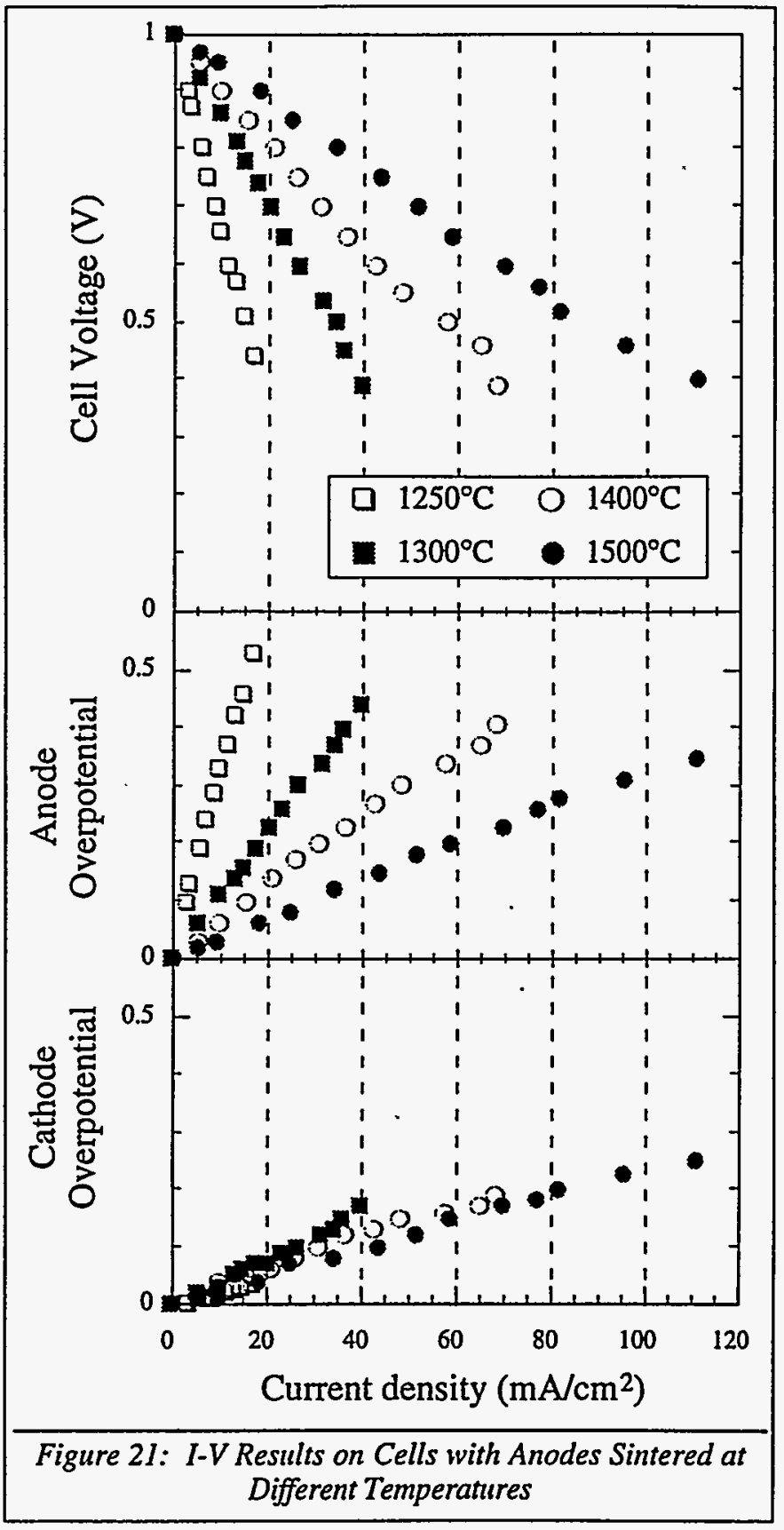

overpotential. Sheet resistance measurements need to be performed on the cathode material to successively separate the cathode overpotential into a IR drop and a nonohmic loss.

From Figure 21 it can be seen that the cell performance increases as the firing temperature increases. The increase in performance with firing temperature is related to the decrease in the potential drop across the anode. The higher firing 
temperature may create a more rigid network of YSZ-YSZ contacts thus reducing the tendency of the $\mathrm{Ni}$ to sinter. Figure 22 is an SEM micrograph of an anode fired on at $1400^{\circ} \mathrm{C}$, reduced and operated under load for 8 hours. The YSZ particle size is approximately $1 \mu \mathrm{m}$ whereas the $\mathrm{Ni}$ particles have coarsened to approximately $5 \mu \mathrm{m}$. Before reduction the YSZ and $\mathrm{NiO}$ particles were both roughly $1 \mu \mathrm{m}$ (Figure 14). The cathode overpotentials are essentially the same for a given current density for all samples. Figure 23 shows the cathode microstructure after load for 8 hours; no changes in microstructure are evident.

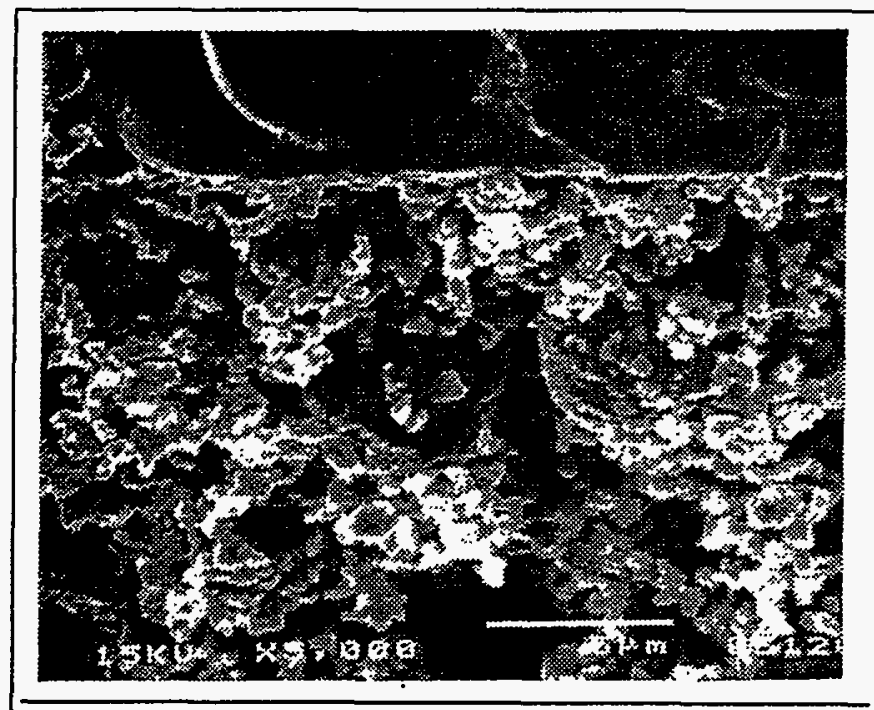

Figure 22: Anode Fired on at $1400^{\circ} \mathrm{C}$; Operated as a Cell for $8 \mathrm{~h}$ at $1000^{\circ} \mathrm{C}$.

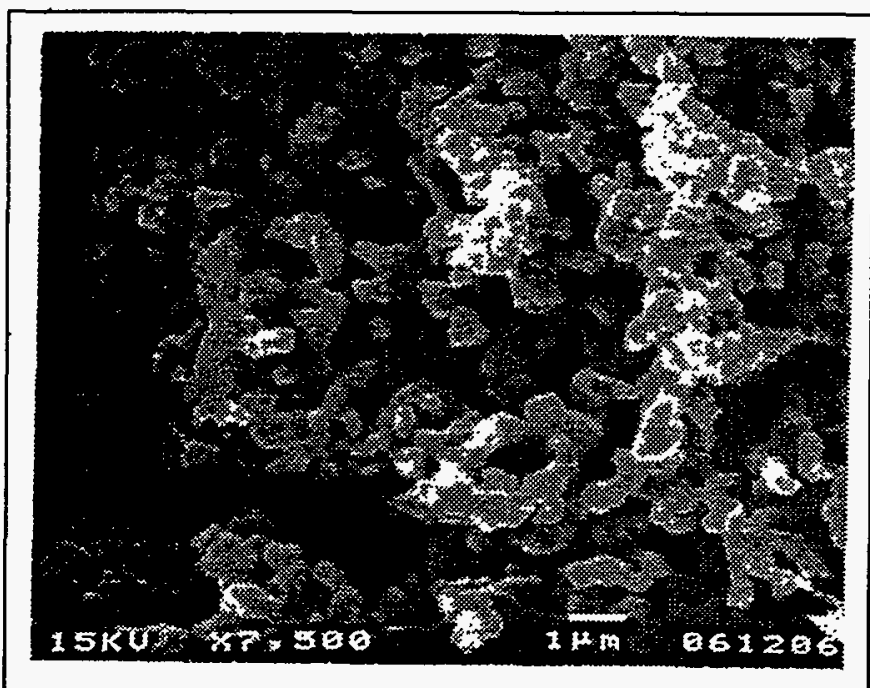

Figure 23: LSM Cathode after Operation as a Cell for $8 \mathrm{~h}$ at $1000^{\circ} \mathrm{C}$.
The effect of $\mathrm{Ni}$ content was investigated with a constant anode and cathode sintering temperature, 1400 and $1100^{\circ} \mathrm{C}$, respectively. The same experimental parameters were used as above (i.e. gas composition, electrolyte thickness, and placement of $\mathrm{Pt}$ reference electrode). Figure 24 shows the improvement of the cell with a higher loading of $\mathrm{NiO}, 54$ versus 43 volume \% $\mathrm{Ni}$ after reduction. The anode overpotential is smaller for a higher Ni loading for a given current density

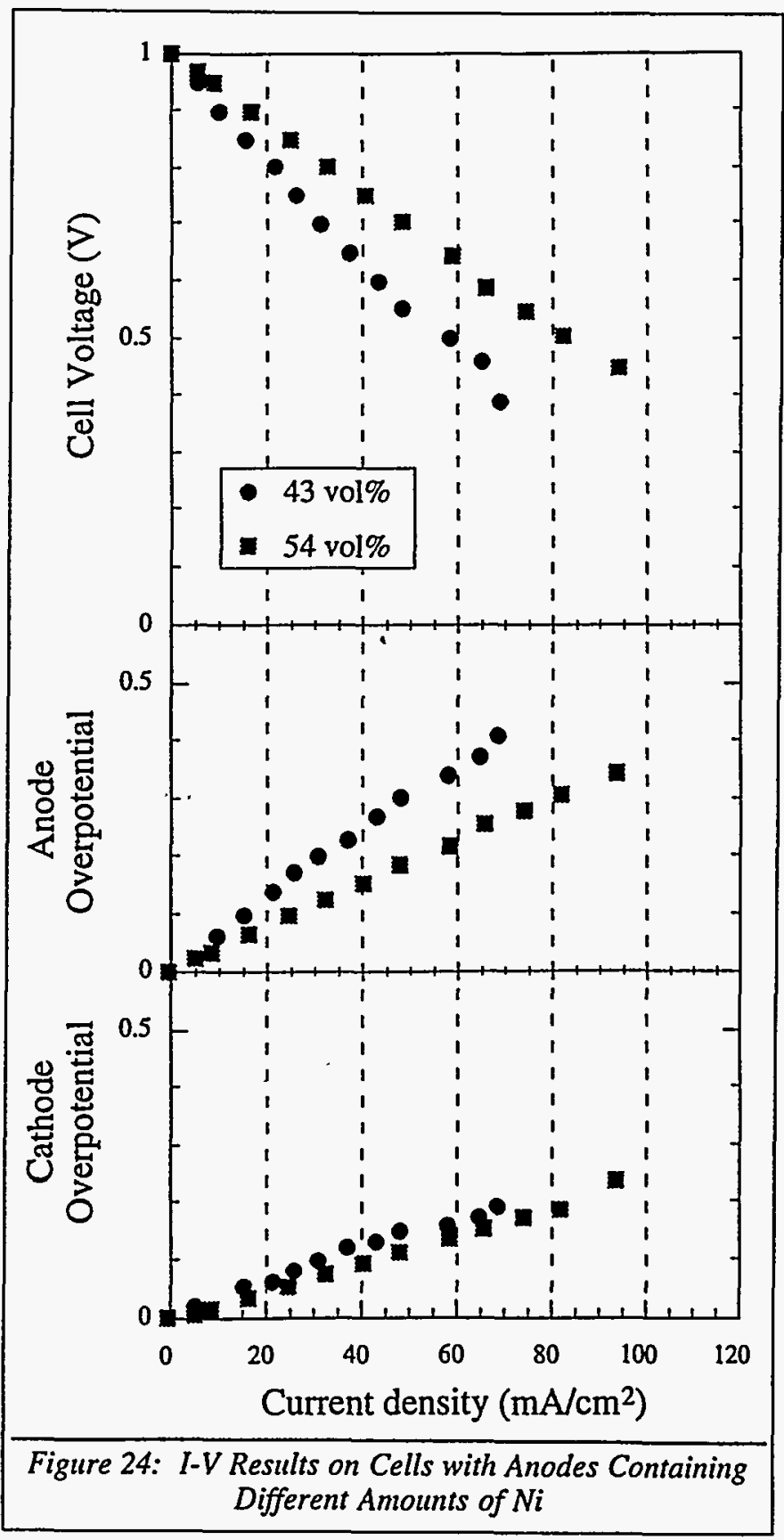


whereas the cathode overpotentials are essentially the same. A reason for the improvement with a higher Ni loading may be that a higher percentage of contact points (three phase boundaries) are present which increase the electrochemical oxidation reaction rate.

The anode composition was also investigated by replacing YSZ with $\mathrm{Sm}$ doped $\mathrm{CeO}_{2}$, a mixed conductor at low oxygen partial pressures. Figure 25 shows the results of samples containing 54 volume \% $\mathrm{Ni}$ after reduction with YSZ versus $\mathrm{Sm}$ doped $\mathrm{CeO}_{2}$. Experimental conditions are the same as described above. There is no significant difference between samples but the Sm doped $\mathrm{CeO}_{2}$ sample does show a slight improvement and a lower overpotential. A possible explanation for the similar results may be that the current density is not high enough to see a significant difference between the two samples. Future investigations will be focus on improving cell performance (i.e. microstructure, anode thickness, etc.) such that the anode composition (YSZ vs. $\mathrm{CeO}_{2}$ ) can be better understood.

Anodes composed of $10 \% \mathrm{MgO}$ doped into $\mathrm{NiO}$

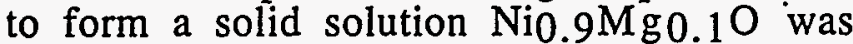
investigated as a function of volume $\% \mathrm{Ni}$ after reduction. Experimental conditions were similar to those given above except $\mathrm{H}_{2}$ bubbling through $\mathrm{H}_{2} \mathrm{O}$ at room temperature was used as fuel. YSZ was used as the other component in the cermet. Figure 26 shows the effect of $\mathrm{Ni}$ content for samples with $10 \% \mathrm{MgO}, \mathrm{MgO}$ additions, and gas composition on cell performance. There is a small improvement with increased $\mathrm{Ni}$ content for samples containing $10 \% \mathrm{MgO}$. The higher $\mathrm{Ni}$ loading may increase the number of reaction sites and thus performance as stated earlier. From the data in Figure 26, the improvement in cell performance can be attributed to $\mathrm{MgO}$ additions or gas composition, although, the exact parameter(s) controlling performance is not known. Experiments aim at understanding this need to be performed (i.e. YSZ-Ni cermet without $\mathrm{MgO}$ utilizing $\mathrm{H}_{2} / \mathrm{H}_{2} \mathrm{O}$ as the fuel). Figure 27 is an SEM micrograph of a Ni-MgO-YSZ/YSZ interface reduced at $1000^{\circ} \mathrm{C}$ for 8 hours. From the micrograph it can be seen that the $\mathrm{MgO}$ is successful in reducing the coarsening effect of the

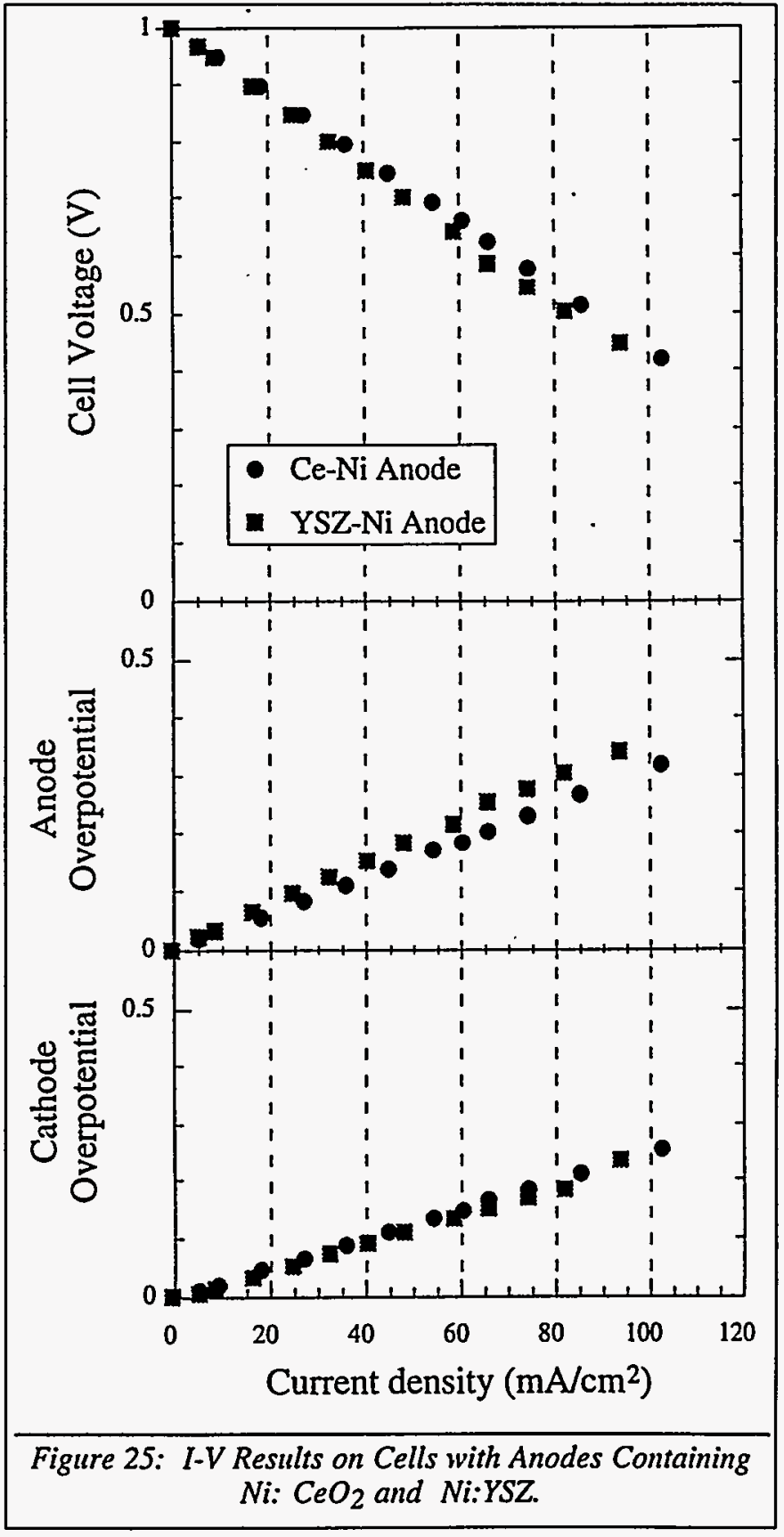

$\mathrm{Ni}$ in comparison to a $\mathrm{Ni}-\mathrm{YSZ}$ cermet with no $\mathrm{MgO}$ additions (Figure 22).

\section{Major Achievements During the Past Year}

- Developed processing skills necessary to fabricate single cells. 
- Incorporated a Pt reference electrode into the electrolyte for separation of electrode effects.

- Developed processing $\leftrightarrow$ microstructure $\leftrightarrow$ property relations for a number of anodes.

- Developed experimental techniques for measuring cell performance.

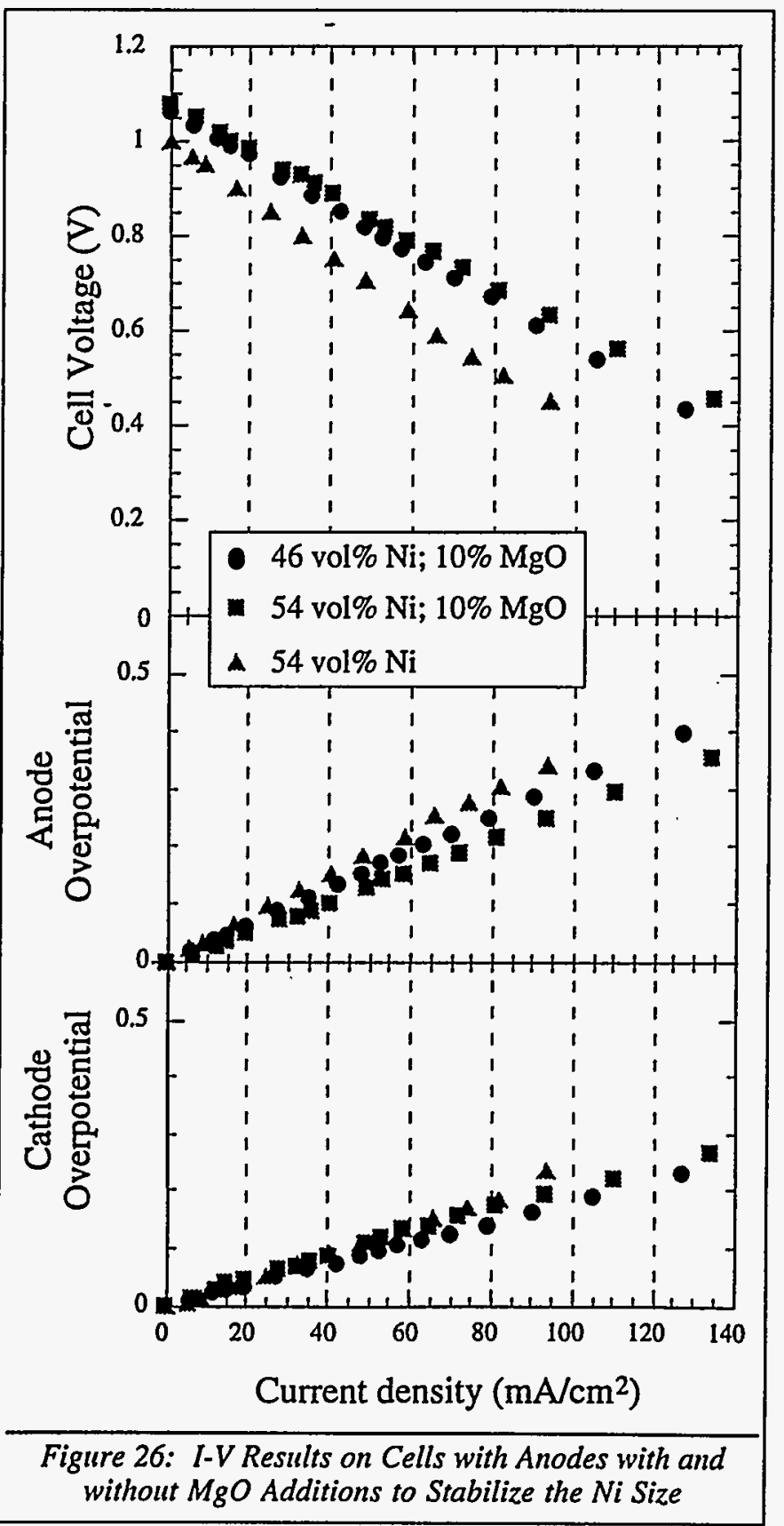

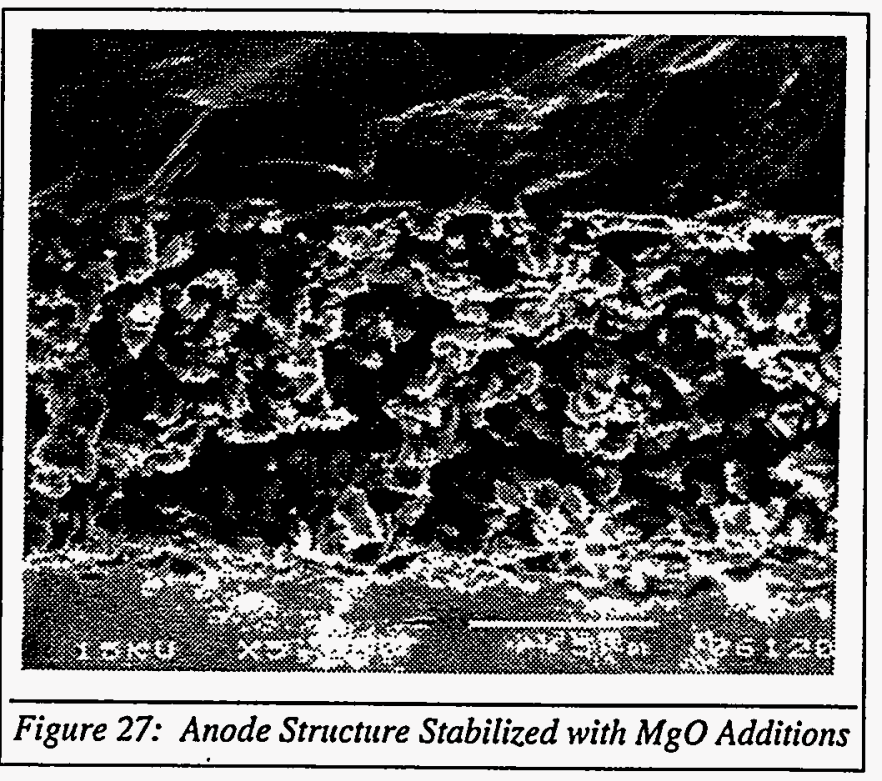

\section{FUTURE WORK}

With respect to the major thrusts of this program:

$$
\mathrm{LACrO}_{3} \text { SINTERING STUDIES }
$$

- Continue development of a non-liquid phase sintered $\mathrm{LaCrO}_{3}$-based material sinterable in air.

- Optimize and control the processing conditions associated with $\mathrm{LaCrO}_{3} \rightarrow$ minimize the particle size and increase the green density.

- Incorporate materials developed in this program into planar cells and measure their performance.

\section{SOFC PERFORMANCE STUDIES}

- Fabricate single cells with controlled microstructures of the cathode; incorporate interfacial modifications to improve the catalytic activity. 
- Gain a better understanding of the mechanisms involved in improving cell performance via electrochemical and impedance techniques.

\section{REFERENCES}

1. H.U. Anderson and M.M. Nasrallah, "Development of Improved Cathodes for Solid Oxide Fuel Cells," Proc. of the $2^{\text {nd }}$ Annual Fuel Cell Contractors Review Meeting, ed. W.J. Huber, pp 171-78, DOE/METC-90/6112.

2. J.D. Carter, M.M. Nasrallah and H.U. Anderson, "Properties of Liquid Phase Sintered $\mathrm{LaCrO}_{3}$ and $\mathrm{YCrO}_{3}$," Ceramic Society Meeting, Cincinnati, $\mathrm{OH}$, April 1991.

3. J.L. Bates, L.A. Chick, and W.J. Weber, "Alternative Materials for Solid Oxide Fuel Cells," Proc. of the 1 st Annual Fuel Cell Contractors Review Meeting, ed. W.J. Huber, pp 54-63, DOE/METC-89/6105.

4. L.A. Chick, J.L. Bates, L.R. Pederson and H.E. Kissinger, "Synthesis of Air-Sinterable Lanthanum Chromite Powders," pp 170-187, Proc. 1 1 st Intl. Symp. SOFC, ed. S. Singhal, Electrochem. Soc., Pennington, N.J. (1989).

5. N. Sakai, T. Kawada, H. Yokokawa and M. Dokiya, "Sinterability and Electrical Conductivity of Ca-doped LaCrO3," J. Mater. Sci., 25:4531-34 (1990).

6. N. Sakai, T. Kawada, H. Yokokawa and M. Dokiya, "Low Temperature Sintering Characteristics of Cadoped $\mathrm{LaCrO}_{3}$," Proc. 2 nd Intl. Symp. on Solid Oxide Fuel Cells, eds. F. Grosz, P. Zegers, S. Singhal, and O. Yamamoto, Athens, Greece, July 1991, pp. 629-636.

7. M. Mori, N. Sakai, T. Kawada, H. Yokokawa and M. Dokiya, "Low Temperature Air-Sinterable Lanthanum Calcium Chromite with Chromium Deficit for SOFC Separator," to be published in Denki Kagaku.

8. B.K. Flandermeyer, R.B. Poeppel, J.T. Dusek and H.U. Anderson, "Sintering Aid for Lanthanum Chromite Refractories," U.S. Patent \#4,749,632, 1988.

9. H.U. Anderson, J.D. Carter, R. Koc, and M.M. Nasrallah, "Air Sinterable Solid Oxide Fuel Cell Interconnects," Fuel Cell Seminar, Phoenix, AZ November 1990, pp. 141-44.

10. L.A. Chick, J.L. Bates and G.D. Maupin, "AirSinterable Mechanisms of Chromites," Proc. 2nd Intl. Symp. on Solid Oxide Fuel Cells, eds. F.
Grosz, P. Zegers, S. Singhal, and O. Yamamoto, Athens, Greece, July 1991, pp. 621-628.

11. L-W. Tai and H.U. Anderson, Better Ceramics Through Chemistry VI, Spring Meeting MRS, April 1994, .

12. C.C. Chen, M.M. Nasrallah, and H.U. Anderson, Solid State Ionics, 70/71, 101-108 (1994).

13. C.C. Chen, M.M. Nasrallah and H.U. Anderson, J. Electrochem, Soc., 140 3555-3560 (1993).

14. C.C. Chen, M.M. Nasrallah and H.U. Anderson, Proceedings of the 3rd International Symposium on SOFC, eds. S.C. Singhal and H. Iwahara, pp. 252266, The Electrochem. Soc., Pennington, NJ 1993.

15. C.C. Chen, M.M. Nasrallah and H.U. Anderson, Proc. 1992 Fuel Cell Seminar, pp 515-58, November 29-December 2, 1992, Tuscon, AZ.

16. H.U. Anderson, W. Huebner, D. M. Reed, C.C. Chen, X. Deng and M.M. Nasrallah, Proceedings of the 1994 Fuel Cell Seminar, pp 49-52, November 28-December 1, 1992, San Diego, CA. 


\section{.}


6

This cover stock is $30 \%$ post-consumer waste and $30 \%$ pre-consumer waste, and is recyclable. 